GOMES, ABS; OLIVEIRA, TRA; CRUZ, DP; GRAVINA, GA; DAHER, RF; ARAÚJO, LC; ARAÚJO, KC. 2018. Genetic gain via REML/BLUP and selection indices in snap bean. Horticultura Brasileira 36: 195-198. DOI: http://dx.doi.org/10.1590/S0102-053620180208

\title{
Genetic gain via REML/BLUP and selection indices in snap bean
}

\author{
Andréa BS Gomes'; Tâmara RA Oliveira'; Derivaldo P Cruz; Geraldo A Gravina'; ${ }^{1}$ Rogério F Daher ${ }^{1}$; \\ Lanusse C Araújo²; Kléberson C Araújoº
}

${ }^{1}$ Universidade Estadual do Norte Fluminense Darcy Ribeiro (UENF), Campos dos Goytacazes-RJ, Brazil; andreabsgomes@gmail.com; tamara_rebecca@hotmail.com; deri.engineer@gmail.com; gravina@uenf.br; rogdaher@uenf.br; ${ }^{2}$ Instituto Federal Fluminense (IFF), Bom Jesus do Itabapoana-RJ, Brazil; laraujo@iff.edu.br; kcordeiro@iff.edu.br

\begin{abstract}
The aim of this study was to compare four selection indexes and REML/BLUP methodology in the evaluation of predicted genetic gains of traits of interest in snap bean breeding program. We evaluated 17 selected lines, in a randomized complete block design, with four replicates, in four environments, Bom Jesus de Itapaboana-RJ, in 2011 and 2012 and Cambuci-RJ, in 2011 and 2013. The evaluated traits were pod and grain productivity, number of pods per plant, number of seeds per pod and weight of 100 seeds. For gain prediction, the employed selection indexes were Pesek \& Baker, Smith \& Hazel, Mulamba \& Mock, Williams and REML/BLUP methodology. Among the tested selection indexes, Mulamba \& Mock was the one which showed the best gain distribution considering the tested variables, such as the higher coincidence coefficients in comparison to REML/ BLUP, resulting in $62 \%$ of grain productivity and pod productivity per plant. The REML/BLUP methodology permitted to select lines with high relative performances and obtained simultaneous gains for the evaluated traits, being superior in relation to the tested selection indexes for snap bean crop.
\end{abstract}

Keywords: Phaseolus vulgaris, simultaneous selection, mixed models.

\section{RESUMO}

Ganho genético via REML/BLUP e índice de seleção em feijão-de-vagem

O objetivo deste trabalho foi comparar quatro índices de seleção e o método REML/BLUP na avaliação de ganhos genéticos preditos das características de interesse ao programa de melhoramento de feijão-de-vagem da UENF. Foram avaliadas 17 linhagens, em delineamento experimental de blocos ao acaso, com quatro repetições, em quatro ambientes, Bom Jesus de Itabapoana-RJ, nos anos $2011 \mathrm{e}$ 2012 e Cambuci-RJ, nos anos 2011 e 2013. Avaliaram-se as características de produtividade de vagens e de grãos, número de vagens por planta, número de sementes por vagem e peso de 100 sementes. Para predição de ganhos, os índices de seleção utilizados, foram Pesek \& Baker, Smith \& Hazel, Mulamba \& Mock, Williams, além da metodologia de REML/BLUP. Entre os índices de seleção testados, Mulamba \& Mock foi o que apresentou a melhor distribuição dos ganhos entre as variáveis avaliadas, assim como, os maiores coeficientes de coincidência comparado com REML/BLUP, resultando em $62 \%$ para produtividade de grãos e produtividade de vagens por planta. O método REML/BLUP permitiu selecionar linhagens com desempenhos relativos altos e obter ganhos simultâneos entre as características avaliadas, sendo superiores em relação aos índices de seleção testados para a cultura de feijão-de-vagem.

Palavras-chave: Phaseolus vulgaris, seleção simultânea, modelos mistos.

\section{Received on March 20, 2017; accepted on October 25, 2017}

$\mathrm{S}^{\mathrm{n}}$ nap bean is a differentiated form of common bean (Phaseolus vulgaris). The final product for consumption is the pod, a food rich in fiber, protein, iron, vitamins, minerals and other nutrients (Trindade et al., 2011).

Snap bean varieties are differentiated among them, mainly in relation to three basic characters: kind of pod, the pod color and growth habit. The snap bean cultivar "manteiga" has flatten-shaped pods in all its extension, whereas "macarrão" type has rounded pods. In relation to pod color, four basic snap bean varieties can be considered: dark green, light green, yellow and purple. The growth habit can be determinate or indeterminate (Vilhordo et al., 1996; Filgueira, 2003).

The ideal harvest date can be considered the one when pods reach maximum growth, before they become fibrous. During harvest, pods must be still tender, the ends being able to be bent and effortlessly broken.

When making inferences about genotypes, in the launch phase, the real genotypic values should be taken into account, it means, the inferences should be based on the genotypic but not fenotypic averages. According to Resende (2007), the structuring of selection procedures, which are responsible for the success of breeding programs, are based on the estimation of variance components and in the prediction of genetic values candidates for selection.

Selection indexes are generally used to choose superior genotypes, based on a complex of variables which gather attributes of breeder's interest, in order 
to result in better simultaneous gains (Cruz, 2004).

Besides the use of selection indexes, mixed model methodology is a trend in plant breeding. These procedures provide additional parameters relevant for the identification of superior genotypes (Maia et al., 2011; Ramalho \& Araújo, 2011).

Ramalho \& Araújo (2011) state the use of mixed models as an appropriate strategy to improve efficiency of autogamous plant breeding, through the identification of progenies or lines with higher genotypic merit. Mendes et al. (2011) used predictions via REML (Restricted Maximum Likelihood Method) and BLUP (Best Linear Unbiased Prediction Method), to identify superior progenies and individuals within segregating populations of common beans. Studies have confirmed the use of mixed models for annual plant breeding in different crops such as soybeans (Pinheiro et al., 2013), cowpea (Barros et al., 2011), common beans (Bertoldo et al., 2009) and popcorn (Freitas et al, 2013).

Although the application of selection indexes has been demonstrated for several crops, in snap beans few studies using this strategy can be found in literature for snap beans.

Given the above, this study aims to compare four kinds of selection indexes and REML/BLUP methodology evaluating the predicted genetic gains of traits of interest in the snap bean breeding program.

\section{MATERIAL AND METHODS}

Seventeen snap bean genotypes $\mathrm{F}_{9-10}$ generation were evaluated, being three controls and the other genotypes were lines from snap bean Breeding Program of Universidade Estadual Norte Fluminense Darcy Ribeiro (UENF). The experiments were installed in two places and in two years: Instituto Federal Fluminense, Campus Bom Jesus de Itabapoana-RJ, in May, 2011 and 2012 and Campus Cambuci-RJ, in May, 2011 and 2013.

The experimental design was randomized blocks, with four replicates, being individual plants evaluated within each replicate. The spacing used was 1 $\mathrm{m}$ between rows and $50 \mathrm{~cm}$ between plants. The experimental plot consisted of $5 \mathrm{~m}^{2}$, using 8 central plants and 2 at the end of the plot as border lines. The values are real and obtained per plot of 10 plants and estimated for 1 hectare.

Two seeds were sown per pit, at $2.5 \mathrm{~cm}$ depth. Plantlets were thinned ten days after emergence, in order to leave only one plant per pit, in both experiments.

About fifteen days after emergence, plants were staked using wires. During the experiment, cultural and phytosanitary practices were done according to recommendations for the crop. Sprinkler irrigation system was adopted. Ten harvests were carried out lasting approximately 120 days.

The following traits were evaluated individually: pod productivity $\left(\mathrm{t} \mathrm{ha}^{-1}\right)$; grain productivity $\left(\mathrm{t} \mathrm{ha} \mathrm{h}^{-1}\right)$; average number of pods per plant; average number of seeds per pod; weight of 100 seeds.

The selection indexes of Smith (1936), Hazel (1943), Williams (1962), Pesek \& Baker (1969) and Mulamba \& Mock (1978) were tested, in order to select 8 superior lines, with selection intensity of $47 \%$. For statistical analyses, values were assigned by attempts, for five evaluated traits. The software GENES (Cruz, 2013) was used for selection of lines based on the selection indexes.

The software SELEGEN WindowsREML/BLUP was used for statistical analyses (Resende, 2007), statistical model 114 (Evaluation in several locations/several years - Annual crops; Complete block design with triple interaction and stability and adaptability). "Interaction locations and years":

$$
\mathrm{y}=\mathrm{Xf}+\mathrm{Zg}+\mathrm{Qa}+\mathrm{Ti}+\mathrm{Wt}+\varepsilon,
$$

in which $\mathrm{y}=$ data vector; $\mathrm{f}=$ vector of the effect of combinations repetitionlocation-year (assumed to be fixed) added to the overall average; $g=$ vector of genotypic effects (assumed to be random) $\mathrm{a}=$ vector of effects of genotype-year interaction (random); $\mathrm{i}=$ vector of the effects of genotype- location interaction; $\mathrm{t}=$ triple (genotypelocation-year) interaction (assumed to be random), and $\varepsilon=$ vector of errors or residues (random). Capital letters represent the incidence matrixes for these effects. Vector $\mathrm{f}$ represents effects of repetitions within locations within years, locations, years and interaction locations $\mathrm{x}$ years.

The coincidence coefficient was obtained through the ratio of double coincident lines between two indices and the total of selected lines, in percentage.

The relative performance of each selected line was calculated using the ratio between the new average of improved population and the new average of improved population showing higher genetic value of the 8 selected lines, in percentage.

\section{RESULTS AND DISCUSSION}

Table 1 shows predicted percentage gains for Pesek \& Baker, Smith \& Hazel, Williams and Mulamba \& Mock selection index, using weights assigned by attempts $(1,1,50,50$, $100)$, comparing with REML/BLUP methodology based on pod productivity, grain productivity, number of pods per plant, number of seeds per pod and weight of 100 seeds.

Pod weight and number of pods per plant showed negative gains of -0.03 and -2.78 , respectively, using Pesek \& Baker index, which is undesirable. Thus, Pesek $\&$ Baker index is not recommended for selection, since the main goal is the simultaneous improvement of evaluated traits (Table 1). Similarly, Bárbaro et al. (2007) did not obtain satisfactory results with this index for superior genotype selection in soybean either.

Mulamba \& Mock indexes showed best gain distribution among the evaluated variables, making them suitable for genotype selection in this study. This index was recommended in other studies, such as the one which provided the best results for superior genotype selection, as the verified in cowpea (Santos \& Araújo, 2001), soybean (Costa et al., 2004) and popcorn (Freitas, 2013).

REML/BLUP methodology was the 
Table 1. Estimates of gains (\%) based on the selection of five traits of snap bean lines. Campos dos Goytacazes, UENF, 2016.

\begin{tabular}{|c|c|c|c|c|c|}
\hline \multirow[b]{2}{*}{ Variables } & \multicolumn{4}{|c|}{ Selection index } & \multirow{2}{*}{$\begin{array}{l}\text { REML/ } \\
\text { BLUP }\end{array}$} \\
\hline & $\begin{array}{c}\text { Pesek \& } \\
\text { Baker }\end{array}$ & $\begin{array}{c}\text { Smith \& } \\
\text { Hazel }\end{array}$ & $\begin{array}{c}\text { Mulamba \& } \\
\text { Mock }\end{array}$ & Williams & \\
\hline PV & -0.03 & 0.13 & 0.83 & 1.87 & 6.31 \\
\hline PG & 5.16 & 7.83 & 8.92 & 8.35 & 15.23 \\
\hline NVP & -2.78 & 2.89 & 2.65 & 4.04 & 14.10 \\
\hline NSV & 0.24 & -0.33 & 0.35 & -0.01 & 4.69 \\
\hline P100S & 9.69 & 6.24 & 7.02 & 5.19 & 16.47 \\
\hline
\end{tabular}

$\mathrm{PV}=$ pod productivity; $\mathrm{PG}=$ grain productivity; $\mathrm{NVP}=$ number of pods per plant; $\mathrm{NSV}=$ number of seeds per pod; $\mathrm{P} 100 \mathrm{~S}=$ weight of 100 seeds.

Table 2. Coincidence coefficients for 8 selected lines using selection indexes and REML/ BLUP methodology, in relation to pod productivity above the diagonal and grain productivity below the diagonal of snap beans. Campos dos Goytacazes, UENF, 2016.

\begin{tabular}{lccccc}
\hline Selection Index & $\begin{array}{c}\text { Pesek\& } \\
\text { Baker }\end{array}$ & $\begin{array}{c}\text { Smith \& } \\
\text { Hazel }\end{array}$ & $\begin{array}{c}\text { Mulamba } \\
\text { \& Mock }\end{array}$ & Williams & $\begin{array}{c}\text { REML/ } \\
\text { BLUP }\end{array}$ \\
\hline Pesek \& Baker & - & 0.62 & 0.62 & 0.62 & 0.50 \\
Smith \& Razel & 0.62 & - & 0.75 & 0.75 & 0.62 \\
Mulamba \& Mock & 0.50 & 0.75 & - & 0.87 & 0.62 \\
Williams & 0.62 & 0.75 & 0.87 & - & 0.62 \\
REML/BLUP & 0.62 & 0.75 & 0.62 & 0.62 & - \\
\hline
\end{tabular}

most efficient in relation to the other tested indexes, since simultaneous improvements of traits were noticed: pod productivity, grain productivity, number of pods per plant and weight of 100 seeds, 6.31, 15.23, 14.10 and 16.47 respectively (Table 1). For Phaseolus vulgaris breeding program, Mendes et al. (2011) used predictions via BLUP, in order to identify superior progenies and individuals within segregating populations. Chiorato et al. (2008) recommend REML/BLUP to guide bean breeding program and Coimbra et al. (2005) for oat breeding program.

Table 2 shows the coincidence coefficients for 8 selected lines, for the four indexes and REML/BLUP methodology, for the two traits considered the most important ones for snap bean crop, which are: pod productivity and grain productivity. The values were high, ranging from 50 to $87 \%$. According to Pedrozo et al. (2009), the higher the coincidence coefficient between two selection indices, the greater will be the agreement of selection results between them.

Table 3. Ranking and estimates of 8 lines, effects $(\mathrm{g})$, predicted genotypic values $(\mathrm{u}+\mathrm{g})$, new average (BLUP) and relative performance (DR), in relation to pod productivity and grain productivity of snap beans. Campos dos Goytacazes, UENF, 2016.

\begin{tabular}{ccccccc}
\hline \multirow{2}{*}{ Ranking } & \multicolumn{7}{c}{ Pod productivity } & & \\
\cline { 2 - 7 } & Line & $\mathbf{g}$ & $\mathbf{u}+\mathbf{g}$ & Gain & New average & DR(\%) \\
\hline 1 & 6 & 2.57 & 31.50 & 2.57 & 31.50 & 100 \\
2 & 7 & 1.96 & 30.90 & 2.27 & 31.20 & 99.04 \\
3 & 13 & 1.65 & 30.58 & 2.06 & 30.99 & 98.38 \\
4 & 2 & 1.40 & 30.33 & 1.89 & 30.83 & 97.81 \\
5 & 12 & 1.15 & 30.09 & 1.75 & 30.68 & 97.39 \\
6 & 20 & 0.52 & 29.46 & 1.54 & 30.48 & 96.76 \\
7 & 9 & 0.39 & 29.32 & 1.38 & 30.31 & 96.22 \\
8 & 3 & -0.33 & 28.59 & 1.16 & 30.10 & 95.55 \\
\hline & & & Grain productivity & & 100 \\
\hline 1 & 2 & 0.95 & 4.70 & 0.95 & 4.70 & 96.38 \\
3 & 20 & 0.61 & 4.36 & 0.78 & 4.53 & 94.25 \\
4 & 3 & 0.49 & 4.24 & 0.68 & 4.43 & 91.70 \\
5 & 13 & 0.19 & 3.94 & 0.56 & 4.31 & 90.21 \\
6 & 12 & 0.18 & 3.93 & 0.48 & 4.24 & 88.93 \\
7 & 7 & 0.18 & 3.93 & 0.43 & 4.18 & 87.65 \\
8 & 5 & 0.02 & 3.77 & 0.37 & 4.12 & 86.80 \\
\hline
\end{tabular}


Comparing the selection indexes with REML/BLUP methodology, the authors could notice that higher coincidence coefficient of selected lines were obtained using Smith \& Hazel index: $0.75 \%$ for grain productivity (Table 2). For pod productivity, all indexes showed coincidence coefficient of $62 \%$, except for Pesek \& Baker index which was $50 \%$. This result can be explained by the fact that REML/BLUP methodology uses, as solution vector, predicted genotypic effects and selection gain individually, completely excluding the environmental effect.

REML/BLUP methodology showed to be the most appropriate in relation to other selection indexes, selecting lines with high relative performance and promising predicted genetic gains for snap bean crop, probably due to the exclusion of environmental effect (Table 3 ). For traits pod productivity, grain productivity and number of pods per plant, 5 lines coincided, of the total of 8 selected lines, using REML/ BLUP, validating the efficiency of this methodology in relation to the other index selections.

The relative performance of progeny was high, when selected lines showed estimates higher than $86.60 \%$, both for PV and PG, which is an evidence of selective accuracy of REML/BLUP methodology. Borges et al. (2010) showed that genotypic values are quite close to the new average and viceversa. Thus, the authors can conclude that this methodology was efficient to select progenies with high relative performance.

\section{REFERENCES}

BÁRBARO, IM; CENTURION, MAPC; MAURO, AOD; UNÊDA-TREVISOLI, SH; COSTA, MM; MUNIZ, FRS; SILVEIRA, GD; SARTI, DGP. 2007. Variabilidade e correlações entre produtividade de grãos e caracteres agronômicos de soja com aptidão para cultivo em áreas de reforma de canavial. Cientifica 3: 136-145.

BARROS, FR; FILHO, CJA; ROCHA, MM; NUNES, JAR; SILVA, KJD; FREIRE FILHO, FR; RIBEIRO, VQ. 2011. Potencial genético de progênies de feijão-caupi segregantes quanto ao tipo da inflorescência. Pesquisa Agropecuária Brasileira 46: 182-189.

BERTOLDO, JG; COIMBRA, JLM; GUIDOLIN, AF; NODARI, RON; ELIAS, HT; BARILI, LD; VALE, NM; ROZZETTO, DS. 2009. Rendimento de grãos em feijão preto: o componente que mais interfere no valor fenotípico é o ambiente. Ciência Rural 39: 1974-1982.

BORGES, V; SOARES, AA; REIS, MS; RESENDE, MDV; CORNÉLIO, VMO; LEITE, NA; VIEIRA, AR. 2010. Desempenho genotípico de linhagens de arroz de terras altas utilizando metodologia de modelos mistos. Bragantia 69: 833-841.

CHIORATO, AF; CARBONELL, SAM; DIAS, LAS; RESENDE, MDV. 2008. Prediction of genotypic values estimation of genetic parameters in common bean. Brazilian Archives of Biology and Technology 51: 465-472.

COIMBRA, JLM; KOPP, MM; SOUZA, VQ; BENIN, G; MARCHIORO, VS; CARVALHO, FIF; OLIVEIRA, AC. 2005. Prediction of genetic value in $\mathrm{f}_{3}$ populations of Avena sativa L. using REML/BLUP. Crop Breeding and Applied Biotechnology 5: 265-271.

COSTA, MM; MAURO, AO; UNÊDATREVISOLI, SH; ARRIEL, NHC; BÁRBARO, IM; MUNIZ, FRS. 2004. Ganho genético por diferentes critérios de seleção em populações segregantes de soja. Pesquisa Agropecuária Brasileira 39: 1095-1102.

CRUZ, CD. 2004. Modelos biométricos aplicados ao melhoramento genético. Viçosa: UFV. 480p.

CRUZ, CD. 2013. GENES - A software package for analysis in experimental statistics and quantitative genetics. Acta Scientiarum 35: 271-276.

FILGUEIRA, FAR; 2003. Novo manual de olericultura: Agrotecnologia moderna na produção e comercialização de hortaliças. Viçosa: UFV. 412p.

FREITAS, ILJ; AMARAL JUNIIOR, AT; VIANA, AP; PENA, GF; CABRAL, PS; VITTORAZZI, C; SILVA, TRC. 2013. Ganho genético avaliado com índices de seleção e com REML/BLUP em milho de pipoca. Pesquisa Agropecuária Brasileira 48: 1464-1471.

HAZEL, LN; 1943. The genetic basics for constructing selection indexes. Genectics 28:
476-490.

MAIA, MCC; RESENE, MDV; OLIVEIRA, LC; ÁlVARES, VS; MACIEL, VT; LIMA, AC. 2011. Seleção de clones experimentais de cupuaçu para características agroindustriais via modelos mistos. Revista Agro@mbiente On-line 5: 35-43.

MENDES, MP; RAMALHO, MAP; ABREU, AFB. 2011. Strategies for selecting individuals in commom bean breeding programs. Bean Improvement Cooperative 54: 68-69.

MULAMBA, NN; MOCK, JJ. 1978. Improvement of yield potential of the Eto Blanco maize (Zea mays. L) population by breeding for plant traits. Egypt Journal 7: 640-51.

PEDROZO, CA; BENITES, FRG; BARBOSA, MHP; RESENDE, MDV; SILVA, FL. 2009. Eficiência de índices de seleção utilizando a metodologia REML/BLUP no melhoramento da cana-de-açúcar. Scientia Agraria 10:31-36.

PINHEIRO, LCM; GOD, PIVG; FARIA, VR; OLIVEIRA, AG; HASUI, AA; PINTO, EHG; ARRUDA, KMA; PIOVESAN, ND; MOREIRA, MA. 2013. Parentesco na seleção para produtividade e teores de óleo e proteína de soja via modelos mistos. Pesquisa Agropecuária Brasileira 48: 1246-1253.

PESEK, J; BAKER, RJ. 1969. Desired improvement in relation to selected índices. Canadian Journal of Plant Science. 49: 803-804.

RAMALHO, MAP; ARAÚJO, LC. 2011. Breeding self-pollinated plants. Crop Breeding and Applied Biotechnology 11: 1-7.

RESENDE, MDV. 2007. Software SELEGENREML/BLUP: sistema estatístico e seleção genética computadorizada via modelos lineares mistos. Colombo: Embrapa Florestas. $359 \mathrm{p}$.

SANTOS, CAF; ARAUJO, FP. 2001. Aplicação de índices para seleção de caracteres agronômicos de feijão de corda. Ciências Agronômicas 32: 78-84.

SMITH, HFA. 1936. Discriminant function for plant selection. Annual Eugenics 7: 240-250.

TRINDADE, RS; AMARAL JÚNIOR, AT; RODRIGUES, R; VIANA, JMS; PEREIRA, MG; GONÇALVES, LSA. 2011. Combining ability for morphoagronomic traits in common bean and snap bean. African Journal of Agricultural Research 6: 6240-6245.

VILHORDO, BW; MIKUSINSKI, OMF; BURIN, ME; GANDOLF, VH. 1996. Cultura do feijoeiro: fatores que afetam a produtividade. Piracicaba: Associação Brasileira para pesquisa da potassa e do fosfato. 1988: 669-700

WILLIAMS, JS. 1962. The evolution of a selections index. Biometrics. 18: 375-393 